\title{
SPECULATIVE AUTHORSHIP: THE FAMILY NARRATIVE AS EDITORIAL PROJECT IN THEODOR STORM'S CARSTEN CURATOR
}

\author{
JOANNA NEILLY
}

\begin{abstract}
Editors take on authorial power when their role moves beyond the recovery and explication of a text to its revision for a specific audience. This article examines the editorial recreation of two types of domestic narrative: national literary history, constructed by philologists; and family records, constructed by patriarchs. Both seek to create a particular image of community and belonging, and so are significant for the popular perception of a coherent, shared culture in the context of nineteenthcentury German nationalism. Via a metaphorical reading of the family in Theodor Storm's novella Carsten Curator, I reveal how the editors of such histories become 'speculative authors': they attempt to construct a narrative of continuity for the future by rewriting a domestic past. Their official records, however, exclude competing narratives that have the potential to undermine these projects. Editorial omission becomes a flawed attempt to achieve authorial control.
\end{abstract}

Keywords: authorship; national identity; German philology; nineteenth century; family; Theodor Storm; Carsten Curator; oral tradition; gossip; Buddenbrooks

\section{Introduction: speculative authorship}

An only child neatly draws two lines under his name in a record book. Just like that, Hanno Buddenbrook ends his family's official history. The action foreshadows his early death and thus the end of the Buddenbrook line. Hanno rejects the linearity of the family chronicle: he does not read his position in the book as part of a teleological development, but rather sees 'das ganze genealogische Gewimmel' [the whole genealogical hodgepodge] and refuses to impose order on it. ${ }^{1}$ When reprimanded, he excuses himself in words whose halting delivery does not conceal their fatal blow: 'Ich glaubte ... ich glaubte ... es käme nichts mehr ...' [I thought ... I thought ... there wouldn't be anything more] (p. 576; p. 510). A blindingly obvious marker in the decline of Lübeck's First Family, this episode might also be read in the light of editorial practices that shaped nineteenth-century philology. The family book is not merely an historical chronicle; it marks an attempt to bring coherence to an unknown future. 
Reading between the lines, present and future Buddenbrooks should hear the authoritative voice of the past and heed their duty to carry on the family tradition. Depending on perspective, Hanno either fails or breaks free from this controlled narrative.

The central focus of this article is the metaphorical link between the authorship of family lives and that of national literature. More precisely, I will read the guardian of family history as a close cousin of the nineteenth-century editor who aimed to delineate a coherent German literary canon. From around the mid-nineteenth century, the bourgeois German family became not only an important market for literature, but also a symbol for the health of the nation. Stories for families, about families, often published in family journals, were a staple of the German literary diet. They helped to create a 'reading nation' in which national identity was reflected in the German household. ${ }^{2}$ Fiction about families therefore provides a lens through which to view the construction of national narratives for the popular imagination. In the following discussion, I will compare the role of a fictional patriarch to that of scholarly editors. Both are in the job of overseeing domestic affairs: the former literally, and the latter by shaping an imagined canon of national literature. Their aim is to propagate a coherent domestic narrative and thus strengthen and entrench the position of the family or the nation. Breaks in coherence, as represented by Hanno's textual vandalism, undermine or even invalidate their careful work.

As my title suggests, however, these narratives can only ever be speculative, because they aim to shape the future. I refer here to editors and fictional fathers as 'speculative authors' because they try to map the forwards trajectory of their respective national/family narratives: in a sense, they are authoring the future bourgeois nation. This desire to order the world may, however, obscure subversive features that do not fit a pre-determined story. If so, the narrative will be based on an incomplete truth, perhaps more palatable to a bourgeois public but structurally unsound. The Buddenbrook family chronicle represents one such narrative; another frustrated effort is undertaken by the eponymous Carsten Curator of Theodor Storm's 1877 novella.

Carsten Curator appeared at a halfway point between the publication dates of two canonical novels about family and business: Gustav Freytag's Soll und Haben (1855) and Thomas Mann's Buddenbrooks (1901). The first affirms the future of the bourgeois German family; the second documents its terminal decline. Storm's novella impressed Mann, who called it '[eine] Erzählung von wunderbar ernster und unerbittlicher Schönheit' [a story with a strikingly serious, unrelenting beauty], and there are similarities between Carsten Curator 
and Buddenbrooks. ${ }^{3}$ While Soll und Haben closes with a celebration of the happy, secure family home, the Carstens and the Buddenbrook houses are sold off after three generations in the families' possession. Like Thomas Buddenbrook, Carsten Carstens tries to maintain an increasingly transparent façade of family integrity. In both cases, the reader is aware of the break between intention and reality, because the narrative style reveals that internal and external views of the family do not match up. Carsten Curator continues in a tradition of realist prose fiction that puts the family at its centre, but it also questions the objective truth of family histories. This hints at wider issues concerning the creation of an authorized literary canon via the exclusion of competing narratives.

Carsten thinks constantly about his own family story and tries to maintain coherence between past and future. He is not an author or editor in the literal sense, although as a curator he works closely with documents to set family finances straight. ${ }^{4}$ Within the broad definition of authorship as creation of a narrative, Carsten works 'speculatively' because he projects his sense of family worth into the future, particularly when dealing with his errant son Heinrich. He bets on the past to secure continuity. But Carsten is undermined by a second type of speculation: the unsubstantiated, although not necessarily untrue, rumour that contradicts or warps the official story. It is a subtle irony of Storm's text that a conservatively-minded patriarch should overlook the value of gossip: oral narrative is, after all, the most traditional form. And yet, thanks to its flexibility and the speed of its circulation, gossip is also preferred by modern business speculators who bet on a changing future rather than stability. The diligent record-keeper Carsten ignores the gossip-mongering broker Herr Jaspers, but the latter grasps the truth about Heinrich more quickly than Heinrich's own father. Jean Buddenbrook, meanwhile, has no idea that his prospective son-in-law Herr Grünlich is a failing businessman, because Grünlich's books are immaculate. But the written record of Grünlich's finances is based on speculation. Grünlich initiates a rumour among business associates that he will marry Tony well before the engagement has taken place; it is against this imagined lucrative marriage that he secures credit and so pleases Jean. This speculation becomes official family history when Tony enters the engagement into the family book, but the Buddenbrooks have their chronology wrong. Jean's praise of the 'Bücher [...] zum Einrahmen!' [books ... worthy of framing!] (p. 122; p. 109) is a subtle indicator that he looks for exemplary past behaviour when he should be listening to current affairs. Gossip and conjecture gain the upper hand over the textual tradition. Speculation, in this sense, is an alternative narrative mode that both pre-dates and pre-empts the written word. The 
painstaking construction of a grand narrative arc cannot compete with its speed. 'Speculative authors' thus fall into two camps: the traditionalists like Carsten and Jean Buddenbrook who seek to impose order on the future via the written word; and the modern opportunists who paradoxically rely on an older but faster form of narrative. If future-oriented authorship is a form of speculation based on the past, its construction fails. If, however, speculation means an ability to adapt the narrative in keeping with an ever-changing modern world, it represents a type of authorship not bound by nineteenth-century editorial convention.

\section{Nineteenth-century editorial practice}

The story of nineteenth-century philology is one of ordering. As Alexander Beecroft writes, 'one of the imperatives of any literary system is to reduce information, to reduce canons to manageable proportions by identifying entire categories of literature that can be ignored and by establishing criteria for what remains. ${ }^{5}$ A national-literature system, operating alongside the nineteenth-century construction of the nation-state, '[assumes] a congruence between territorial units of political and cultural authority'. 6 This solves the problem of what can be included/excluded on linguistic grounds, but the rediscovery in this period of vernacular texts opened up a vast cultural hinterland which, if it were to serve nationalist aspirations, had to be organized into a unified literary history reaching from the medieval to the modern. ${ }^{7}$ Editors came into their own as the authors of national philology. In the nineteenth century, when 'the very concept of a German literary history was still being fashioned', collected editions became the mark of canonization. ${ }^{8}$ The consensus that a scholarly critical edition still represents the highest honour for an author is testament to the enduring power of this phenomenon in shaping authorial success. ${ }^{9}$ Editors played their part in authoring an accessible German literary history, traced along a timeline that realized 'national literature's dream of chronological depth'. ${ }^{10}$ Their importance comes from the fact that the collected edition is far from an unadulterated product. It takes many editorial interventions to produce an authentic original. In dealing with medieval manuscripts, Romantic nationalists in the first half of the century, such as the Grimms, searched for the Urtext, an object of unassailable authenticity and therefore a legitimizing force for cultural nationalism. This, however, did not mean reprinting individual manuscripts, but working through variants and fragments to produce a single new manuscript that would get to the heart of the original author's intention via editorial reconstruction. '[C]orrupted variants or incomplete fragments of a lost origin' would give way to one genuine artefact, but the latter could only be decisively produced via 
careful and selective editing. ${ }^{11}$ Inevitably, some aspects were stressed at the expense of others, which in the context of nineteenth-century nationalism often meant prioritizing an imagined Germanic character. For example, the scholarly revival of the thirteenth-century poet Wolfram von Eschenbach was, according to Todd Kontje, a German 'repatriation' that overlooked Wolfram's cosmopolitan tendencies. ${ }^{12}$

The method of the philologist Karl Lachmann (1793-1851) aimed for scientific objectivity by producing the most technically accurate version of a work, purged of errors so that the new version would be 'better than any extant text' ${ }^{13}$ His editorial method was carried on by Franz Muncker (1855-1926), who took up Lachmann's Lessing edition of 1838-40 and worked on a revised version between 1886 and 1924. ${ }^{14}$ But even Lachmann's 'reduction of all questions of meaning to philological facts' did not preclude 'excising, adapting and ordering'. ${ }^{15}$ Editorial transparency is a myth:

The critical edition rested on the paradoxical idea that it was only through the practice of transformation that the editor could recover something that was originally there. The more the editor did, in other words, the more he disappeared from the author's text. ${ }^{16}$

Scholarly authority provided the justification for editorial streamlining. The jobs of collecting literature, ordering it, and explaining it were conflated: the earliest professors of literature and literary history in Germany were often also the university librarians, like Jacob Grimm in Göttingen. ${ }^{17}$ Pioneers in philology were archivists or indeed professional historians, such as Georg Gervinus (1805-71) and Wilhelm Scherer (1841-86). But while literary history blossomed in the service of cultural nationalism, the literary present was also seeking a place in the canon. Richard R. Ruppel identifies a tension experienced by the historian who also tries to judge the literature of his day: how can the strategies employed to interpret literature as an historical phenomenon apply to living authors whose oeuvre is not yet complete ? $^{18}$ And yet authors of the long nineteenth century lived to see the canonization of their work in the form of the critical edition. ${ }^{19}$

Two potential chinks appear in the editor's armour. First, the editor necessarily excludes some detail, because order trumps comprehensiveness. Second, ability to read the past does not guarantee understanding of the present. The ordering of literary triumphs into one uninterrupted trajectory shows that aspirations for the national literary future are tinged by a longing for the past. The collected edition 'fashion[ed] a unified literary corpus out of a diverse and often heterogeneous array of texts' to afford 'the imaginative possibility that 
something stayed the same'. ${ }^{20}$ That is, the collected edition legitimized reproduction, by reproducing a regulated version of national literature that achieved historic status as soon as it entered the market.

In my metaphorical reading, the nuclear family corresponds to the 'original' text produced by editors. Both are seemingly manageable entities, and both are a microcosm, whether of the German nation or of its literature. Both are also less coherent than they may appear, and their seeming adherence to a tightly-controlled narrative masks, but does not necessarily overcome, internal differences. Like editors, the patriarchs of fictional German families control their histories by excluding outside narratives and resisting diversity.

In realist literature, the bourgeois family came to represent a channel through which to explore national ambitions, both before unification in 1871 and in shaping the idea of the German nation thereafter. Critics have long been aware of the role of Heimatliteratur in constructing popular views of the nation, and relations between the family and the community provided a means of exploring, on a smaller scale, the relationship between local and national. ${ }^{21}$ At the micro-level, a family in which each member willingly functions as part of a whole provides an ideal model for the nation at large. Family stories set in recognizable communities were published in journals such as Die Gartenlaube - an 'illustrirtes Familienblatt' [illustrated family paper] - and the aptly-named Unterhaltungen am häuslichen Herd [Conversations by the domestic hearth]. Carsten Curator appeared in Westermanns illustrirte deutsche Monatshefte, which likewise targeted a family readership. As the smallest unit of belonging after the individual, the family is situated on one end of a sliding scale of group identity that proceeds through the family firm, the local Heimat, the nation and finally the wider world. ${ }^{22}$ These points on the scale might be better imagined as concentric circles or Russian dolls - each larger structure magnifies the immediately smaller one, but also threatens to engulf it.

At the centre of Carsten Curator and Buddenbrooks are the family and the family home; more significant for the families' survival are their businesses, which are part of the culture of Husum and Lübeck respectively. The local Heimat is in turn infiltrated by the wider nation. Heinrich Carstens and Christian Buddenbrook travel to Hamburg for business, while Tony's marriages take her to Hamburg then Munich; these characters return home with tales of their experiences. Finally, increasingly globalized trading practices affect the physical and the imagined landscapes back home, and present a challenge to family - or metaphorically, national - integrity. Carsten owns exotic seashells, a gift from a sea captain 
with whom his father traded wool; he hears of an attack on a Flensburg student by a 'Negerjunge' [young black man] who has presumably arrived in the port town via the colonial trade route with the Danish Antilles; ${ }^{23}$ and a speculator returns from England and influences Heinrich's poor business decisions. Local, national, and global forces are paradoxically all contained within a specific Heimat, representing what Dirk Göttsche and Roland Berbig describe as an area of tension between the German province and the German metropolis. ${ }^{24}$ Traces of the global connections forged in major cities and ports are evident even within the provincial German home. ${ }^{25}$

The overlapping of various spaces that occurs in a globalizing world presents a chance to absorb what might appear as threatening outside influences into familiar stories of home, provided that an editorial form of control is adhered to. ${ }^{26}$ Opportunity and danger go hand in hand. Thomas Buddenbrook travels to Amsterdam for an important business apprenticeship, and returns with a Dutch wife. But Gerda's fundamentally different disposition results in the birth of an unsuitable heir who defaces the family history. In Storm's novella, a stay in Hamburg - a thriving global trade centre - speeds Heinrich's moral decline. Incursions from the outside world cannot be avoided, but a defence mechanism appears in the form of structured narratives that aim to neutralize the threat. These are the stories that families tell about themselves. A few final words on the potential editorial pitfalls are necessary before moving on to a closer reading of Carsten Curator.

As discussed above, the definitive corpus of selected national authors was editorially authorized. Controlled reproduction recasts fragments and variations into one complete image of representative authors and texts. However, in a rapidly expanding print culture, this repetition could get out of hand, so that the numerous collected editions produced from the Romantic era onwards 'contributed to the very surplus of production they were designed to control' ${ }^{27}$ The control is meant to emanate outwards from the smallest unit: the canon is authored at home by a few philologists and then circulated more widely, but this does not account for external influences that undermine the project (e.g. alternative editions). To borrow Benedict Anderson's term, the 'imagined community' evoked by representative authors should remain intact when exported for consumption. Returning to family narratives via my Russian doll metaphor, this sameness should apply on any level, so that the representation of a German family is also one of a community, which is in turn a representation of the nation. Such a scale can theoretically be traced in both directions without the essential image changing, in a manner similar to the paradoxical universal 
singularity of a national author: '[T] he more collected editions unified and stabilized an author's works, the more such works could paradoxically circulate among the populace. ${ }^{28}$ But this only works if internal control is tightly maintained and the image/edition retains its stability. The flaw in this kind of thinking is suggested by Raymond Williams's 'knowable communities' ${ }^{29}$ In Williams's reading, realist fiction based in specifically local areas Hardy's rural southern England, or indeed Storm's Nordfriesland - reproduces the appearance of an easy familiarity. However, this deceptive ease of recognition blurs 'persistent rural disturbance[s]', and is exposed, in a more critical reading, as a 'retrospective condition' ${ }^{30}$ The supposedly unified value system of a small community is produced in the present as 'a particular and private sensibility', with the result that nostalgic subjectivity invents a false historical objectivity. ${ }^{31}$ In other words, the recreation of the small community or even the family, like the editorship of collected editions, is a mode of authorship that constructs an imagined historic ideal from fragments, and projects it into the present and beyond.

\section{Fragmenting families, narrative uncertainties}

Carsten Curator is a case study for the intersection of editorial control, narrative construction and family tradition. Carsten Carstens, as head of his family, is a metaphorical editor because he successively tries to manage his family's story and its future. The reader follows Carsten from his forties into old age and ultimate mental decline. His understanding of his own family undergoes a parallel decline. As the narrative progresses, Carsten finds it increasingly difficult to determine the actions of his son Heinrich, and he loses control over his family's fate. The story begins during the years of the Napoleonic Continental Blockade (1806-14). Carsten Carstens inherits the family wool shop, but leaves the day-to-day business to his sister Brigitte because he is also a financial trustee for widows and single young women. Hence his unofficial name 'Carsten Curator'. Despite some misgivings, the forty-year-old agrees to act as curator for Juliane, a much younger woman whose father has hanged himself after a failed business gamble. Carsten falls in love with Juliane and they marry; she dies giving birth to their son Heinrich. Carsten cherishes Juliane's memory but is haunted by her flirtation with a French sea captain. Heinrich, a flighty character, takes after his mother. Carsten also adopts a daughter, Anna, who relies on him as her financial guardian. Heinrich is financially irresponsible, gambling away money entrusted to him by his employer and then moving to Hamburg where he continues to lose money at an alarming rate; Carsten pays his 
considerable debts. A solution to Carsten's worries comes when Heinrich returns to Husum and marries Anna. The family business expands with the acquisition of a second shop, jointly run by the newlyweds. This happy interlude is brief. Heinrich is again tempted into risky speculation and chips away at Anna's inheritance. Finally, during a stormy night culminating in a catastrophic flood, Heinrich begs Carsten for help one last time, asking him to release the remainder of Anna's money. Carsten prioritizes his role as curator over his (by now sorely tested) paternal duty and turns his son away. Later that night, Heinrich drowns in the flood. Carsten consequently suffers a stroke, Anna spends her remaining money on a memorial, and the family house is auctioned off. The novella closes on a sentimental but ultimately pathetic note, with the aged Carsten in the care of his adoptive daughter.

Existing scholarship emphasizes Carsten's conflicting desires to secure the family's financial future and to help his son. Each of these desires manifests itself as a will to control. Michael White's outstanding article demonstrates how Carsten's efforts to return Heinrich to the straight and narrow become an almost obsessive form of surveillance, while Monique Barasch describes 'un amour paternel à outrance' [an excessive paternal love]. ${ }^{32}$ White argues that the field of vision provides a framework for paternal control. Carsten prefers to watch over his son quite literally, and Heinrich's return to Husum temporarily fulfils this desire. The local Heimat is 'a realm of relative safety because an individual can be observed and watched over', but White identifies the moral ambiguity: '[S]urveillance as care brings with it dangers of control., 33

Closer to my own focus is an essay by Hartmut Pätzold which reads Carsten's efforts to maintain a middle-class identity as a fraught navigation between traditional family reputation and the diverging interests of individual subjects. ${ }^{34}$ Pätzold argues that while Storm's characters tend towards nostalgia, his fiction resists conservative readings because the same characters are attracted to outside influences that subvert tradition. So, the reliable curator marries the frivolous Juliane, who cares nothing for books, symbolically at a time when French seamen flood the town, so that the threats to personal and national integrity go hand in hand. Since Carsten's respectable public identity is undermined by his private desires, his 'Flucht in den bürgerlichen Traditionalismus' [escape into bourgeois traditionalism] is ineffectual. ${ }^{35}$ Pätzold imaginatively connects Carsten's suspension between past and future and his attraction to otherness in a postmodern reading. If Carsten tries to subsume conflicts into one clear vision of his family, this belies the ambivalence of literary 
meaning that Storm exposes at the level of narrative. ${ }^{36}$ Pätzold's reading thus recalls the 'persistent [...] disturbances' of Williams's '[un]knowable communities' 37

My contribution to this discussion concerns narrative construction at the intrinsic level of the plot. It is striking how much attention the story pays to modes of telling and retelling, not to mention the textual nature of Carsten's chosen role as curator and his related preference for fixed narratives over stories passed on by word of mouth. Keeping in mind 'the imaginative possibility that something stayed the same' afforded by editors, I will read Carsten's refusal to engage in oral modes of narration, whether traditional storytelling or more insidious gossip, as a manifestation of his will to regulate his family by preventing change. ${ }^{38}$ This exclusion of alternative narratives is a form of editing, designed to keep the family story intact by continuing the respectable ancestral line evoked in the novella's first sentence: 'Eigentlich hieß er Carsten Carstens und war der Sohn eines Kleinbürgers, von dem er ein schon vom Großvater erbautes Haus an der Twiete des Hafenplatzes ererbt hatte' [His name was actually Carsten Carstens, the son of a small merchant in the town, from whom he had inherited a house built by his grandfather that stood at the corner of the Twiete] (p. 456; p. 35). Interestingly, this very sentence undermines its own show of consistency with its casual beginning: Carsten Curator is actually called Carsten Carstens, but the family name has been all but erased by his unofficial job.

Carsten's reputation is based on bookishness, which is why the community relies on his judgement in cases of doubt; the opening paragraph tells us that even as a young boy he was interested in all sorts of written materials. He has 'eine Neigung zur Gedankenarbeit' [a somewhat inquisitive disposition], but he does not talk about his thoughts; indeed, should his reading provoke new intellectual discoveries, he keeps them to himself so as not to startle others and thus lose their confidence (p. 456; p. 35). He shields his intellectual life from public circulation; it is lived only between his mind and his books. When Juliane says 'Bücher? Ich weiß nichts davon' [Accounts? I don’t know anything about them] (p. 458; p. 37), it is an early indication of her patent unsuitability for Carsten. His ability quickly to bring order to her father's books is in stark contrast to his inability to read her: 'wozu sie eigentlich ihre Zeit verbrauchte, konnte er nie erforschen' [how she actually spent her time he could never discover] (p. 459; p. 37). The exotic seashells in Carsten's room once illustrated stories of adventure abroad, passed on from a sea captain to Carsten's father; Carsten declines to retell these stories and instead uses the shells as paperweights for all kinds of written documents (p. 469; p. 47). His personal library comprises a combination of local histories and 
canonical German works. If his mental life partly separates him from his community, this interest in the local and the national nonetheless marks him out as a typical late nineteenthcentury Kleinbürger, for whom commitment to one's own community is simultaneously a celebration of Germanness more generally. ${ }^{39}$ But Carsten's attachment to fixed written narratives and his disregard for stories that circulate orally mean that he misses significant aspects of community life with a direct bearing on his family.

Carsten's avoidance of spoken stories extends to an abhorrence of gossip. This isolates him, for indulgence in gossip is not necessarily a moral lapse, but an important marker of social belonging:

the right to gossip about certain people is a privilege which is only extended to a person when he or she is accepted as a member of a group [...]; if a man does not join in the gossip and scandal, he shows that he does not accept that he is a party to the relationship. ${ }^{40}$

Gossip bridges the gap between public and private life, it helps to form a 'local speech community', and carries 'informal power' in its exchange value. ${ }^{41}$ Those who do not partake may be viewed as outsiders with pretensions to superiority. Moreover, they miss out on an informal means of ordering and control that bypasses official information channels. If a gossiper can draw out others to talk, he can learn to 'arrang[e] a constant flow of information to himself' and so to manage 'a powerful social instrument' ${ }^{42}$ Gossip therefore serves both community identity and individuals who wish to gain power within their community. By filling in gaps and circulating at speed, gossip furnishes unofficial and up-to-date narratives that escape the written record. As a narrative form, it destabilizes monolithic histories by giving credence to alternative versions of events. Its practitioners are well-positioned to adapt to change; their future is predicated on insecurity.

In Carsten Curator, Herr Jaspers is a gossip par excellence. His 'Altweiberstimme' [old woman's voice] (p. 464 and p. 493; p. 42 and p. 68) reminds us that gossip has traditionally been dismissed as women's talk, a mode of communication for the domestic sphere. ${ }^{43}$ This impression is enhanced by Jaspers's tendency to speak in old-fashioned clichés and proverbs. But Jaspers is in fact the most powerful man in the novella, not least because he grasps the value of gossip as 'a cultural device used by the individual to forward his own interests'. ${ }^{44}$ A representative of the modern speculative capitalism that affects even provincial life, Jaspers is a middleman in two senses: professionally, as a broker; and socially, as he 
processes and passes on information about the townspeople's affairs. The speed at which this information circulates informally means that Jaspers is always one step ahead of Carsten, even when it comes to Carsten's family. Jaspers is the one to inform Carsten that Heinrich has gambled away the Senator's money and so lost his first apprenticeship; Jaspers realizes well before Carsten that Heinrich will not come home for Christmas because he is enjoying Hamburg life too much; and he suggests that Carsten buy a shop for Heinrich before Carsten even knows that the current owners have gone bankrupt. Inevitably, Jaspers profits by brokering the sale of Carsten's home, by which point Carsten is no longer even capable of understanding practical matters: following his stroke, he is a 'zum Kind geworden[er] Mann' [man who had become a child] (p. 521; p. 93). Jaspers's ability to understand families and his concomitant gain in power are in inverse proportion to Carsten's weakening grip on the details of his own life. And yet, Carsten intuits the potential of gossip to change his family fortunes. When Heinrich finally does come home at Easter, looking every inch a man of the world, Carstens is secretly disappointed that Jaspers is not in church to see him, a tacit acknowledgement that reputation is a matter of public opinion.

Despite this insight, Carsten cannot overcome his aversion to Jaspers, to gossip, and to storytelling more generally. As noted above, he does not retell the stories of foreign lands passed down from his father; for him the stories are not pleasurable diversions but provoke mysterious thoughts that he must process and rationalize, 'für deren Verarbeitung er nur auf sich selber angewiesen war' [in the elaboration of which he had to rely on himself] (p. 469; p. 46 and p. 47). This is further evidence for Pätzold's argument that Carsten is both attracted to and threatened by otherness. In a similar vein, he never speaks to Heinrich about Juliane. This turns out to be a mistake, for Heinrich learns about his mother from the very same French captain with whom Juliane once flirted, and the captain's version of events entrenches Heinrich's sense that he is her son, not his father's:

ich habe meine Mutter nicht gekannt, aber ich habe von ihr gehört - nicht zu Hause, mein Vater hat mir nie von ihr gesprochen, ein alter Kapitän in Hamburg, der in seiner Jugend einst ihr Tänzer war, erzählte mir von ihr - sie ist schön gewesen; aber sie hat auch nichts Anderes wollen, als nur schön und fröhlich sein; für meinen Vater ist ihr Tod vielleicht ein Glück gewesen - ich hatte oftmals Sehnsucht nach dieser Mutter. (p. 509)

[I never knew my mother, but I've heard much about her - not at home, my father has never spoken to me about her; an old captain in Hamburg told me about her, who was her dancing partner once in his youth. She was very beautiful; but she wanted nothing more than to be 
beautiful and happy; her death perhaps was fortunate for my father - I've often yearned for my mother] (p. 82)

While Carsten makes sense of even the most confused written accounts, he often has lapses in hearing or is unable to speak. He tells his sister how he saw Juliane and the sea captain speaking 'Worte, die ich nicht verstehen konnte' [words, which I couldn't understand] (p. 477; p. 53); this traumatic experience is mirrored in the final showdown when the storm drowns out Heinrich's words. He speaks haltingly about Juliane, (p. 477; p. 54), and he fails to tell Anna about the worst of Heinrich's misdemeanours, 'Er versuchte zu sprechen; aber die Worte wollten nicht über seine Lippen' [He tried to talk, but the words would not pass his lips], (p. 505; pp. 78-9). Speech is recognized as the currency of difficult truths. Anna urges Heinrich to come clean by asking him multiple times to speak, 'Nun sprich! [...] Sprich rasch [...] Sag's nur! [...] Warum sprichst du nicht? So erzähl doch! [...] Sag' nur [...] Sprich nur rasch!' [So, tell me! ... hurry up ... Just say it! ... Why don’t you say something? ... Tell me!] (pp. 467-68; p. 45). Even Carsten understands the cathartic potential of talking when he asks his sister to listen to his memories rather than consign them to the past, 'laß mich es endlich einmal sagen!' [Let me say it at last!] (p. 476; p. 53). Nevertheless, he feels compelled to pull away from the man with all the stories. Upon Jaspers's approach, Carsten instinctively takes hold of Anna's hand, as if protecting her (p. 463; p. 42), and while Jaspers is 'unerschütterlich' [[he] stood firmly] (p. 483; p. 59), Carsten's voice becomes weak and uncertain in his presence (p. 464; p. 42). Jaspers's threat is his readiness to share information that could derail the Carstens family history. For this reason, Carsten tries to belittle his mode of narration, “"Ich kenne alle Eure Geschichten, Jaspers,” erwiderte Carsten ungeduldig' [“I’ve heard all your stories, Jaspers”, replied Carsten impatiently] (p. 482; p. 59).

Carsten and Jaspers are opposing types of 'speculative author'. Keen to retain his family's financial stability, Carsten constructs a falsely respectable narrative that appears complete. Jaspers's financial future, conversely, relies on a flexible narrative as he keeps his eye on an ever-changing market. He attends to the latest news, which may be undesirable but, unlike Carsten's records, is actually accurate. Carsten initially enjoys more respect than the broker. For example, the mayor welcomes him warmly but refers to Jaspers as the 'Stadtunheilsträger' [the town's bearer of bad news] (p. 463; p. 41). Carsten's studious engagement with books has earned him the reputation of reliability. But he is not above lies of omission, and although Jaspers is an obnoxious man, he speaks the truth that Carsten 
hides. Carsten excises the worst of Heinrich's sins from the written record when he destroys a letter from Hamburg detailing the scale of his son's debt after a failed business venture. Carsten burns the document and never mentions it at home. The upshot is that Anna wrongly believes Heinrich's mistakes to be in the distant past and is unaware of his most recent offence. Her misguided decision to accept his proposal is based on Carsten's intentionally incomplete account. Meanwhile, the real version of events has spread via word of mouth from the mayor's office, to Jaspers, to the weighmaster. The truth flies, and falsehood comes limping after it.

Carsten's lapse is symptomatic of the ongoing conflict of interests occasioned by his curatorial role. For if Carsten spends his time meticulously putting other people's lives back together, this necessarily means that families must fall apart in the first place for him to make his reputation. Fathers or husbands die, sometimes after destroying their family's financial stability, and Carsten becomes the acting patriarch, an editorial role of sorts in which he untangles 'Vermögensverwirrung' [confused finances] to balance the books (p. 459; p. 38). When it comes to his own family, however, this consolidation is not so easy. The need for a curator is logically in opposition to a stable nuclear family. This natural tension is clear when Carsten conflates his curatorial and his family relationships, first when he becomes a father figure to Juliane but then marries her, and second when he allows his charge Anna, who has been like a sister to Heinrich, to become his wife. This second misguided union results in a vision of family life so perfectly ordered that the reader suspects an ironic undertone:

Mit dem Eckhause an der anderen Seite der Twiete beginnt vom Hafenplatz nach Osten zu die Krämerstraße, deren gegenüberliegende Häuserreihe, am Markt vorüber, sich in der langen Süderstraße fortsetzt. Dort, in einem geräumigen Hause, wohnten Heinrich und Anna. Vor dem Laden auf dem geräumigen Hausflur wimmelte es an den Markttagen jetzt wieder von einkaufenden Bauern, und Anna hatte dann vollauf zu tun, die Gewichtigeren von ihnen in die Stube zu nötigen, zu bewirten und zu unterhalten; denn das gewandte und umgängliche Wesen ihres Mannes hatte die Kundschaft nicht nur zurückgebracht, sondern auch vermehrt. (p. 506)

[The corner house opposite the Twiete marks the beginning of the Krämerstrasse, whose southern row of houses stretches eastwards from the harbour square past the market place and continues on into the long Süderstrasse. There, in a large house, lived Heinrich and Anna. On market days the spacious entrance to the shop now teemed again with customers from the surrounding farms, and Anna had quite enough to do encouraging the most influential among them into the living room for refreshments and conversation; for 
the confident and sociable manner of her husband had not only brought the customers back but also increased their numbers] (p. 79)

Here we see three units of belonging functioning in perfect harmony: family, business and local community are mutually beneficial. The thriving shop is a microcosm of the busy market town; its situation on the ground floor of Heinrich and Anna's home suggests a seamless border between family and community life, or private and public. Heinrich, at last, can replicate the work of his forefathers, who complete the final stages of the scale familyfirm-Heimat-nation-world because their wool clothing is sold to sailors who traverse global trade routes. Mediated through a family-run, local trade, the outside world is no longer a threat but simply an extension of a known life. But this cannot last, because Carsten's role requires family collapse. He finally realizes this when Heinrich's last request pushes him to breaking point and his double identity as father/curator breaks down:

Dein Vater? [...] Ja, Heinrich! - Aber ich war noch etwas Anderes - die Leute nannten mich danach- nur ein Stück noch habe ich davon behalten; sieh zu, ob du es aus meinen alten Händen reißen kannst! Denn - betteln gehen, das soll dein Weib doch nicht, weil ihr Curator sie für seinen schlechten Sohn verraten hat! (pp. 515-16)

[Your father? ... Yes, Heinrich! But I used to be something else as well - people nicknamed me after it - and I've kept a part of that; see if you can tear that from my hands if you will! Go begging then! Your wife shall never have to do that because her trustee betrayed her for the sake of his decadent son!] (p. 88)

Carsten Carstens and Carsten Curator cannot co-exist in a dual identity. Ultimately, the adopted name wins out, erasing the legitimate family line. Indeed, this family line can only be threatened if a curator steps in, because his role is to replace the father. Try as he might to control the family future by reconstructing the imagined wholeness of the past, Carsten undermines his own efforts because his work is built on fragmented narratives.

\section{Conclusion}

Editors and patriarchs assume the authorial power of creation when they shape their own version of literary or family history. The editorial role is not neutral if it involves rewriting. Carsten is a metaphorical editor, recalling the work of those who created 'a domesticized and domesticizing philology'. ${ }^{45}$ In attempting to construct a unifying narrative, Carsten claims authority over his family's story but fails to accommodate competing versions. As a trustee, 
he deals in fragments but makes a virtue of order, smoothing away the incoherence that characterizes the past. Reading the truncated Carstens saga as a metaphor for edited literary history, we are reminded that domestic (family, local, national) narratives are incomplete if they are confined by a single editorial voice. Histories of domestic continuity are authored for posterity, at the expense of the nuances and contradictions that give a fuller picture. Fastmoving, flexible oral narratives are the bearers of complex truth, and traditionalists ignore speculation at their peril. Storm's work thus paves the way for modernist authors' mistrust of teleology, as seen in Buddenbrooks. Moving further into the twentieth century, this will become a mistrust of canonicity in fiction about authors: in another study, the struggling Schiller of Mann's Schwere Stunde (1905) might merit a comparison with Gustav von Aschenbach, who experiences the living death of his own canonization.

\section{NOTES}

\footnotetext{
${ }^{1}$ Thomas Mann, Buddenbrooks. Verfall einer Familie. Roman, ed. by Eckhard Heftrich, in Mann, Große kommentierte Frankfurter Ausgabe, ed. by Heinrich Detering and others (Frankfurt a.M.: S.
} Fischer, 2002), I.i: (2002), p. 575. Translation from Thomas Mann, Buddenbrooks: The Decline of a Family, trans. by John E. Woods (New York: Alfred A. Knopf, 1994), p. 510. Subsequent references will be made in the main body of the text.

${ }^{2}$ See Publishing Culture and the 'Reading Nation': German Book History in the Long Nineteenth Century, ed. by Lynne Tatlock (Rochester, NY: Camden House, 2010). On the link between domesticity and national identity, see Nancy R. Reagin, Sweeping the German Nation: Domesticity and National Identity in Germany, 1870-1945 (Cambridge: Cambridge University Press, 2007).

${ }^{3}$ Thomas Mann, Theodor Storm Essay, ed. by Karl Ernst Laage (Heide: Westholsteinische Verlagsanstalt Boyens \& Co., 1996), p. 30.

${ }^{4}$ It should be noted that 'curator' is used here in its now outdated sense, meaning a financial guardian, in Carsten's case for families or single women whose fathers have died.

${ }^{5}$ Alexander Beecroft, An Ecology of World Literature, from Antiquity to the Present Day (London and New York: Verso, 2015), p. 239.

${ }^{6}$ Ibid., p. 206.

${ }^{7}$ Ibid., p. 229.

${ }^{8}$ Richard R. Ruppel, Gottfried Keller and his Critics: A Case Study in Scholarly Criticism (Columbia, SC: Camden House, 1998), p. 10. 
${ }^{9}$ Helmut Müller-Sievers, 'Reading without Interpreting: German Textual Criticism and the Case of Georg Büchner', Modern Philology, 103.4 (2006), 498-518 (p. 498).

${ }^{10}$ Beecroft, An Ecology of World Literature, p. 229.

${ }^{11}$ Andrew Piper, Dreaming in Books: The Making of the Bibliographic Imagination in the Romantic Age (Chicago and London: University of Chicago Press, 2009), p. 92.

${ }^{12}$ Todd Kontje, German Orientalisms (Ann Arbor: University of Michigan Press, 2004), pp. 112-13. Beecroft similarly writes that the birth of 'national literature' as a literary category required 'the supplanting of the cosmopolitan past' (p. 202).

${ }^{13}$ Müller-Sievers, 'Reading without Interpreting', p. 502.

${ }^{14}$ Ernst Osterkamp, 'Muncker, Franz', in Neue Deutsche Biographie, 18 (1997), <http://www.deutsche-biographie.de/pnd11718165X.html> [accessed 26 July 2017].

${ }^{15}$ Müller-Sievers, 'Reading without Interpreting', p. 502; Pier Carlo Bontempelli, Knowledge, Power, and Discipline: German Studies and National Identity, trans. by Gabriele Poole (Minneapolis and London: University of Minnesota Press, 2004), p. 16.

${ }^{16}$ Piper, Dreaming in Books, p. 93.

${ }^{17}$ See Joep Leerssen, 'The Nation's Canon and the Book Trade', in Editing the Nation's Memory: Textual Scholarship and Nation-Building in Nineteenth-Century Europe, ed. by Dirk Van Hulle and Joep Leerssen [= European Studies, 26 (2008)], 305-17 (p. 310).

${ }^{18}$ Ruppel, Gottfried Keller and his Critics, p. 12.

${ }^{19}$ See Piper pp. 53-54 for an account of Wieland's reception of his own critical edition, and Ruppel, Gottfried Keller and his Critics, p. 3 on Keller's critical edition.

${ }^{20}$ Piper, Dreaming in Books, pp. 55 and 56.

${ }^{21}$ See Celia Applegate, 'Heimat and German Identity', in Applegate, A Nation of Provincials. The German Idea of Heimat (Berkeley and Los Angeles: University of California Press, 1990), pp. 1-19; and The German Bestseller in the Late Nineteenth Century, ed. by Charlotte Woodford and Benedict Schofield (Rochester, NY: Camden House, 2012).

${ }^{22}$ On the interlinking of family and firm, see Ernest Schonfield, 'Buddenbrooks as Bestseller', in The German Bestseller, ed. Woodford and Schofield, pp. 95-112 (pp. 99-100); on the interlinking of firm and nation see, in the same volume, Benedict Schofield, 'Gustav Freytag's Soll und Haben: Politics, Aesthetics, and the Bestseller', pp. 21-38 (pp. 22-26).

${ }^{23}$ Theodor Storm, Carsten Curator, in Sämtliche Werke, ed. by Karl Ernst Laage and Dieter Lohmeier, 4 vols (Frankfurt a.M.: Deutscher Klassiker Verlag, 1987-88), II, pp. 456-522 (p. 482). Subsequent references will be made in the main body of the text. Translation from Theodor Storm, Carsten the Trustee, trans. by Denis Jackson (London: Angel Classics, 2009), p. 59. In this instance the translator has chosen to replace the offensive term 'Negerjunge' ['negro boy'] with a more 
acceptable alternative, but the original expression, as well as being typical of its era, hints at the cultural fear of otherness and outsiders, which I will go on to discuss in the article.

${ }^{24}$ Roland Berbig and Dirk Göttsche, 'Einleitung', in Metropole, Provinz und Welt: Raum und Mobilität in der Literatur des Realismus, ed. by Berbig and Göttsche (Berlin and Boston: De Gruyter, 2013), pp. 1-14 (p. 2)

${ }^{25}$ See Dirk Göttsche, “"Tom Jensen war in Indien”: Die Verknüpfung europäischer und außereuropäischer Welten in der Literatur des Realismus', in Metropole, Provinz und Welt, ed. Göttsche and Berbig, pp. 17-52 (p. 18).

${ }^{26}$ On the overlapping of spaces, see Göttsche and Berbig, p. 31.

${ }^{27}$ Piper, Dreaming in Books, p. 82

${ }^{28}$ Ibid., p. 58.

${ }^{29}$ Raymond Williams, 'Knowable Communities', in Williams, The Country and the City (Nottingham: Spokesman, 2011), pp. 165-81.

${ }^{30}$ Ibid., pp. 166 and 180.

${ }^{31}$ Ibid. p. 180.

${ }^{32}$ Michael White, 'Tyranny and Tragedy: Paradigms of Surveillance in Theodor Storm's Aquis Submersis and Carsten Curator', Seminar, 52.4 (2016), 364-81; Monique Barasch, 'Carsten Curator de Théodore Storm: un héros balzacien d'Outre-Rhin?', The USF Language Quarterly, 21.3-4 (1983), 33-34 (p. 34).

${ }^{33}$ White, 'Tyranny and Tragedy', pp. 376 and 374.

${ }^{34}$ Hartmut Pätzold, 'Der verunsicherte Bürger. Bemerkungen zum Paradigma misslingender pluripolarer Identität in "Carsten Curator", in Gerd Eversberg and others, Stormlektüren. Festschrift für Karl Ernst Laage zum 80. Geburtstag (Würzburg: Königshausen \& Neumann, 2000), pp. 129-41 (p. 135).

${ }^{35}$ Ibid., p. 139.

${ }^{36}$ Ibid., p. 133.

${ }^{37}$ See notes 29 and 30.

${ }^{38}$ Piper, Dreaming in Books, p. 56.

${ }^{39}$ See Applegate, 'Heimat and German Identity'.

${ }^{40}$ Max Gluckman, 'Gossip and Scandal', Current Anthropology, 4.3 (1963), 307-16 (p. 313). See also Johanna Fürstenberg, Die Klatschgespräche in Theodor Fontanes Gesellschaftsromanen. Eine Analyse von 'L'Adultera' und 'Effi Briest' (Hamburg: Literatur \& Wissenschaft, 2011), particularly pp. 25-32.

${ }^{41}$ Melanie Tebbutt, Women's Talk? A Social History of 'Gossip' in Working-Class Neighbourhoods, 1880-1960 (Aldershot: Scolar Press, 1995), pp. 78 and 11. 
${ }^{42}$ Robert Paine, 'What is Gossip About? An Alternative Hypothesis', Man, 2.2 (1967), 278-85 (p. 283); see also Patricia Meyer Spacks, 'In Praise of Gossip', The Hudson Review, 35.1 (1982), 19-38 (p. 30).

${ }^{43}$ See Meyer Spacks, 'In Praise of Gossip', pp. 19-20, and Tebbutt, Women 's Talk? in general.

${ }^{44}$ Paine, 'What is Gossip About?', p. 282.

${ }^{45}$ Bontempelli, Knowledge, Power, and Discipline, p. 17.

\section{[JOANNA NEILLY}

THE FAMILY NARRATIVE IN THEODOR STORM'S CARSTEN CURATOR] 